\title{
Seroprevalence and risk factors for hepatitis B and C virus infection in Damietta Governorate, Egypt
}

\author{
A. Edris, ${ }^{1}$ M.O. Nour, ${ }^{2}$ O.O. Zedan, ${ }^{2}$ A.E. Mansour, ${ }^{2}$ A.A. Ghandour ${ }^{2}$ and T. Omran ${ }^{3}$
}

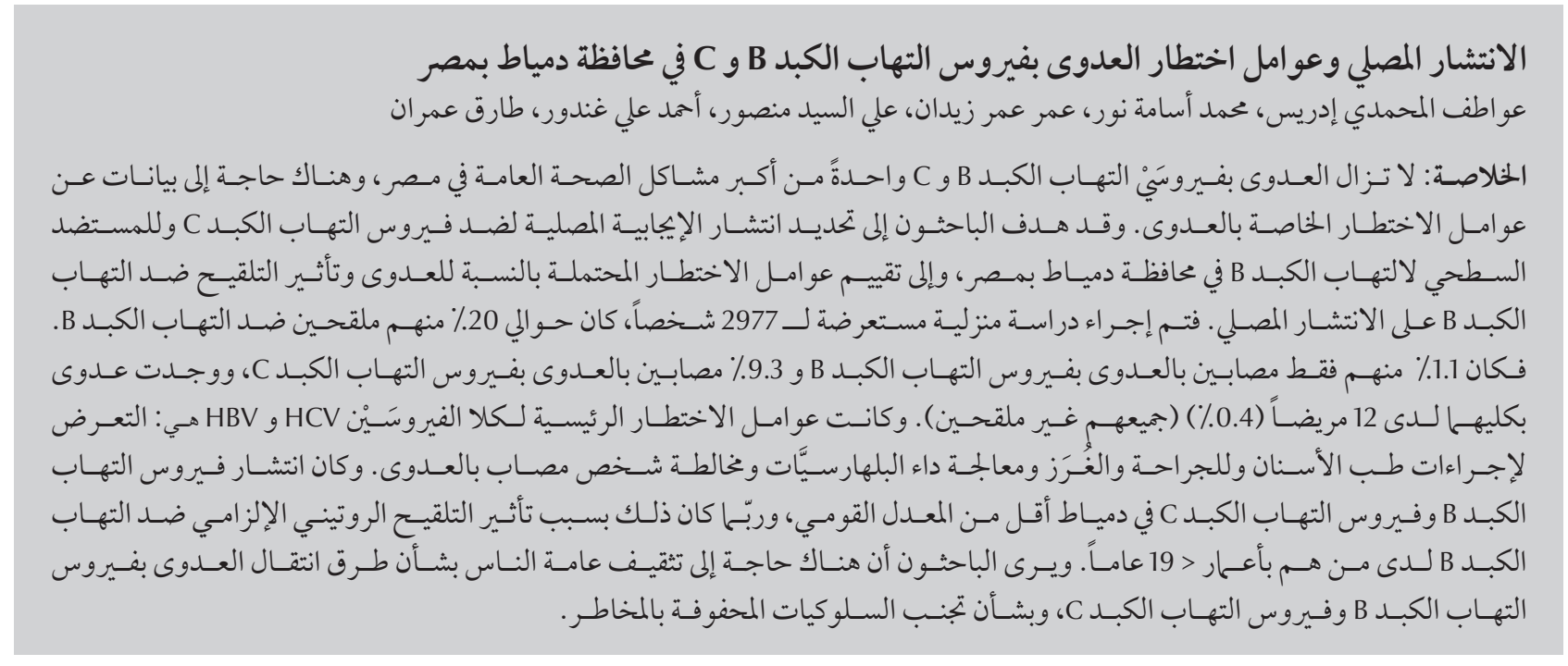

ABSTRACT Hepatitis B and C virus (HBV and HCV) infections remain major public health problems in Egypt and data are needed on risk factors for infection. This study determined the prevalence of anti-HCV and HBV surface antigen seropositivity in Damietta Governorate, Egypt, and evaluated potential risk factors for infection and the impact of HBV vaccination on seroprevalence. A household, cross-sectional study was conducted of 2977 individuals. About $20 \%$ were vaccinated against HBV. Only 1.1\% were infected with $\mathrm{HBV}$ and $9.3 \%$ with $\mathrm{HCV}$; both infections coexisted in 12 people (0.4\%) (all unvaccinated). The main risk factors for both HCV and HBV were exposure to dental procedures, surgery, stitches, schistosomiasis treatment and contact with infected person. HBV and HCV prevalences in Damietta were lower than the national rate, likely due to the routine compulsory HBV vaccination in those aged $<19$ years. There is a need to educate the general population about HBV and HCV transmission routes and avoidance of risky behaviours.

Séroprévalence et facteurs de risque pour l'infection par le virus de l'hépatite B et C dans le gouvernorat de Damiette (Égypte)

RÉSUMÉ L'infection par le virus de l'hépatite B et C (VHB et VHC) reste un problème de santé publique majeur en Égypte et des données sur les facteurs de risque pour cette infection sont nécessaires. L'étude a permis de déterminer la prévalence de la séropositivité à l'antigène de surface du VHB et VHC dans le gouvernorat de Damiette (Égypte), et d'évaluer les facteurs de risque potentiels d'une infection ainsi que l'impact de la vaccination contre le VHB sur la séroprévalence. Une étude transversale auprès des ménages a été menée impliquant 2977 personnes. Environ 20 \% étaient vaccinés contre le virus de l'hépatite B. Seul 1,1 \% était infecté par le virus de I'hépatite B et 9,3\% par le virus de l'hépatite C; les deux infections coexistaient chez 12 patients (0,4 \%), tous étant non vaccinés. Les interventions dentaires et chirurgicales, les points de suture, le traitement de la schistosomiase ainsi que le contact avec des personnes infectées étaient des facteurs de risque majeurs pour les deux infections par le virus de l'hépatite B et C. La prévalence du virus de l'hépatite B et C à Damiette était inférieure aux taux nationaux, peut-être en raison de l'influence de la vaccination systématique obligatoire contre le virus de l'hépatite B chez les moins de 19 ans. Il est nécessaire d'éduquer la population générale aux modes de transmission du virus de l'hépatite B et $\mathrm{C}$ et aux moyens d'éviter les comportements à risque.

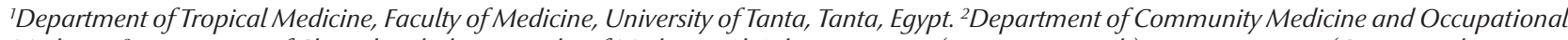
Medicine; ${ }^{3}$ Department of Clinical Pathology, Faculty of Medicine, Al-Azhar University (Damietta Branch), Damietta, Egypt (Correspondence to M.O. Nour:Drmun78@yahoo.com).

Received: 18/11/13; accepted: 25/05/14 


\section{Introduction}

The human hepatitis B and $\mathrm{C}$ viruses (HBV and $\mathrm{HCV}$ ) are major health problems worldwide and cause a wide spectrum of clinical manifestations ranging from an apparently healthy carrier state to acute self-limited or fulminant hepatitis and later to chronic liver disease which is frequently associated with liver cirrhosis that ultimately develops into hepatocellular carcinoma (the 5th most common cancer in the world) $(1,2)$. $\mathrm{HBV}$ and $\mathrm{HCV}$ are biologically different viruses. HBV contains a DNA genome while $\mathrm{HCV}$ is an RNA virus. Their routes of transmission are similar, however, which raises the possibility of co-infection and super-infection of hepatocytes (3). In hepatitis $C$ the rate of progression from chronic hepatitis through cirrhosis to cancer is dramatically higher than that in hepatitis B. The pathogenesis of dual infection and biological interactions between HBV and HCV has not yet been clearly established (4).

The epidemiology and specific risk factors for $\mathrm{HBV}$ and $\mathrm{HCV}$ infections in developing countries are quite different from those of developed countries and, given the high prevalence of $\mathrm{HCV}$, it is of utmost importance to identify risk factors for infection so that intervention programmes may be appropriately focused (5). In Egypt, the situation is especially concerning. Hepatitis B and $\mathrm{C}$ are major public health problems, and will remain so for some time, and the prevalence of hepatitis $\mathrm{C}$ is the highest in the world. The national prevalence of positive $\mathrm{HCV}$ antibodies has been estimated to be between $10.0-15.0 \%$ in rural areas, with some age groups suffering rates of up to $50 \%$. The incidence is estimated to be $2-6$ per 1000 per year (6). In addition, HBV and HCV infection rates differ in different settings, and prognosis may be worse in conjunction with schistosomiasis in Egypt (7).

HCV genotype 4 represents over 90\% of cases in Egypt. Genotype 4 has an intermediate resistance to treatment and for this reason Egyptian patients must undergo longer courses of treatment: 48 weeks instead of the 24 weeks recommended for patients infected with genotypes 2 and 3 (8). In Egypt, the major route of exposure appears to be due to injection therapy and inadequate infection control practices. Also, other non-medical routes have become more common, such as tattooing, circumcision and other medical procedures performed by non-medical personnel. In addition, household transmission, vertical transmission and sexual transmission are routes that are also under investigation (7). However, the significance and weights of these risk factors in different governorates have not been specifically reported in the literature. Prior to 1994 the major risk factor associated with $\mathrm{HCV}$ infection was blood transfusion and before 1986 it was a history of antischistosomial injection treatment. Thus, farmers and rural populations were at greatest risk, and this is supported by the higher prevalence of $\mathrm{HCV}$ in the Nile Delta and rural areas (6).

Egypt is still battling with viral hepatitis and needs to activate and prioritize the national control strategy with regular surveillance and monitoring, enhancement of infection control practices, awareness campaigns, full vaccination coverage, proper patient management and successful research programming in order to combat the hepatitis B and C epidemic. Hence, we aimed to determine the prevalence of anti-HCV and hepatitis B virus surface antigen (HBsAg) seropositivity in the Damietta Governorate of Egypt, and evaluate potential risk factors for transmission of infection as well as the impact of $H B V$ vaccination on seroprevalence.

\section{Methods}

\section{Study design and setting}

The practical part of the study was carried out in the period from December 2011 to September 2012 in Damietta
Governorate, located in the north Nile Delta area, which is composed of 5 districts including rural and urban societies: Kafr Saad, Fareskour, El Zarqa, Damietta and Kafr El Batikh (9). Using multistage random sampling, 1 village or city (as a cluster) was chosen from each district. Thus, the sample consisted of 3 villages (El Swalem, Sharbus, Shermissah) and 2 cities (Ezbet Elborg, Kafr El Batikh) representing the 5 districts respectively. In these selected areas a household survey was conducted by choosing all residents of 1 in every 3 houses, excluding infants and children aged $<5$ years, to avoid inconvenience to parents and difficulties in blood sampling.

\section{Data collection}

The data were collected by an interview questionnaire which included: sociodemographic data (age, sex, residence, marital status, education and occupation); history of hepatitis B vaccination; risk factors (history of previous exposure to surgical operations, dental procedures, stitches, blood transfusion, schistosomiasis treatment, contaminated needles or puncture, endoscopic examination, suction tube, cauterization or renal dialysis); and risky behaviours [shared use of toothbrushes or shaving razors, wet cupping (higama), tattooing or sexual intercourse outside of marriage]. Higama is a traditional therapy whereby blood is drawn by vacuum from a small skin incision.

\section{Serology}

Viral serologyincluded HBsAg, hepatitis $\mathrm{C}$ antibodies (HCV-Ab) and hepatitis $B$ core antibody (HBcAb) for positive HBsAg. Participants were analysed in 2 age groups that reflected vaccination status: < 19 years (i.e. HBV vaccinated, confirmed by history taking) and age $\geq 19$ years (i.e. unvaccinated, as vaccination against $\mathrm{HBV}$ was only enrolled in compulsory immunization in Egypt after 1991). 
Blood specimens were collected by venepuncture and allowed to clot. Serum was separated by centrifugation then was kept frozen at $-20{ }^{\circ} \mathrm{C}$ until assay. Estimation of $\mathrm{HBsAg}$ and anti-HCV was done using ELISA kits (Fortress Diagnostic Ltd). Estimation of anti-HBc was done using competitive immunoassay (enzyme-linked immunosorbent assay) by a 1-step in vitro diagnostic kit for the detection of total antibodies to hepatitis B virus core antigen. The assay was intended to investigate acute or chronic HBV infection and to identify subjects with previous exposure to HBV.

\section{Ethical issues}

The ethical and administrative issues were considered and the study was approved by the institutional review board of Al-Azhar University. Verbal consent was taken from the heads of households after simple explanation about the purpose of the study and the benefit they would get and that personal and medical data would be confidential and used for scientific research only. In addition, the serological results were provided to the subjects on completion and kept strictly confidential. Any infected subjects and their household were provided with appropriate information on the prevention of further spread of these infections and were referred to the nearest government medical facility for guidance.

\section{Statistical analysis of data}

Statistical analysis was carried out using the SPSS computer package, version 17.0. The collected data were statistically managed as follows. For descriptive statistics the mean and standard deviation (SD) were used for quantitative variables. The number and percentage were used for qualitative variables. For analytic statistics the chi-squared test was used to assess the differences in frequency of qualitative variables, while Fisher exact test was applied if any expected cell values in a $2 \times 2$ table was $<5$. Logistic regression analysis was done to predict and rank the relationship between different studied variables. The statistical methods were verified, assuming a significant level of $P<0.05$.

\section{Results}

\section{Sociodemographic characteristics of the study sample}

The total number of subjects selected was 2977, of whom 619 (20.8\%) were assumed to be $\mathrm{HBV}$ vaccinated (i.e. age $<19$ years). However, among older subjects (age $\geq 19$ years), only 87 of 2358 (3.7\%) had been vaccinated (single dose). The mean age of the total sample was 33.9 (SD 15.6) years, range 5-82 years; $54.5 \%$ were males, $71.1 \%$ lived in rural areas and $62.8 \%$ were married. More than half of participants (53.1\%) were not enrolled in the education system, including those who were illiterate, could just read and write or were still below the age of school entry. Students represented $20.6 \%$ and those who were not working comprised $39.8 \%$ of the total sample (Table 1).

\section{Risk factors \& risky behaviours of the study sample}

As regards the risk factors and risky behaviours of the study sample, more than half of them (56.7\%) had been exposed to dental procedures, $34.6 \%$ had undergone surgery, $33.2 \%$ had received stitches, $18.1 \%$ had received bilharzia treatment (intravenous and/ or oral therapy), $17.2 \%$ had a history of contact with infected persons, $13.6 \%$ had shared shaving razors and $9.9 \%$ had history of blood transfusion. A minority of them $(<5.0 \%)$ had been exposed to endoscopic examination, wet cupping, shared toothbrushes, contaminated needle-stick, cauterization, extramarital intercourse, acupuncture, tattoos, intubation for suction or renal dialysis.

\section{Seropositivity for $\mathrm{HBsAg}$ and anti-HCV}

As regards the laboratory results of infection with viral hepatitis, only 32 participants (1.1\%) were seropositive for $\mathrm{HBsAg}$ (15 males and 17 females), with a mean age 41.2 (SD 12.2) years and the majority of them (31 subjects) had chronic infection that was confirmed by HBcAb. Seropositivity for anti-HCV was confirmed in $278(9.3 \%)$ of participants ( 160 males and 118 females), with a mean age of 43.6 (SD 14.4) years. The overall infection rate was $10.0 \%$ in the study sample.

Both infections coexisted in $12 \mathrm{pa}-$ tients ( 5 males and 7 females) and all of them were $\geq 19$ years (HBV unvaccinated). They represented $37.5 \%$ of those with HBV infection, $4.3 \%$ of those with HCV infection and $0.4 \%$ of the total participants. Significantly more of the HBV-positive cases (37.5\%) than HBVnegative cases $(9.0 \%)$ were $\mathrm{HCV}$ positive (Table 2).

\section{Sociodemographic characteristics of HBV- and HCV-infected cases}

Regarding HBV infection, no statistical significant differences were found between negative and positive cases regarding sociodemographic factors of the study sample, except for age and marital status. Those who were ever married and of older age (which reflects HBV vaccination status) were more likely to be HBV positive (Table 3).

In contrast, statistical significant differences were found between negative and positive cases of $\mathrm{HCV}$ infection regarding all the studied sociodemographic factors, except for sex. Those who were older age, rural residents, ever married, never been in education and not working or of "other" occupation were more likely to be $\mathrm{HCV}$ positive (Table 4).

\section{Risk factors \& risky behaviours of HBV- and HCV-infected cases}

Concerning risk factors and risky behaviours of those with HBV infection, statistically significant differences were 


\begin{tabular}{|c|c|c|}
\hline \multirow[t]{2}{*}{ Characteristic } & \multicolumn{2}{|c|}{$\begin{array}{c}\text { Total sample } \\
(n=2977)\end{array}$} \\
\hline & No. & $\%$ \\
\hline \multicolumn{3}{|l|}{ Age (years) } \\
\hline$<19$ (HBV vaccinated) & 619 & 20.8 \\
\hline 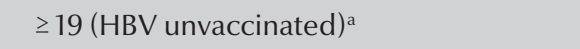 & 2358 & 79.2 \\
\hline \multicolumn{3}{|l|}{ Sex } \\
\hline Male & 1621 & 54.5 \\
\hline Female & 1356 & 45.5 \\
\hline \multicolumn{3}{|l|}{ Residence } \\
\hline Urban & 861 & 28.9 \\
\hline Rural & 2116 & 71.1 \\
\hline \multicolumn{3}{|l|}{ Marital status } \\
\hline Below marital age ${ }^{b}$ & 513 & 17.2 \\
\hline Single & 430 & 14.4 \\
\hline Married & 1869 & 62.8 \\
\hline Widow & 148 & 5.0 \\
\hline Divorced & 17 & 0.6 \\
\hline \multicolumn{3}{|l|}{ Education } \\
\hline Below school entry age & 6 & 0.2 \\
\hline Illiterate (never been in education) & 1073 & 36.0 \\
\hline Read and write (never been in education) & 504 & 16.9 \\
\hline Enrolled in education system ${ }^{c}$ & 613 & 20.6 \\
\hline No longer in education system & 781 & 26.2 \\
\hline \multicolumn{3}{|l|}{ Occupation } \\
\hline Student & 613 & 20.6 \\
\hline Administrator & 194 & 6.5 \\
\hline Other & 984 & 33.1 \\
\hline Not working ${ }^{d}$ & 1186 & 39.8 \\
\hline
\end{tabular}

${ }^{a}$ Only 87 of $2358(3.7 \%)$ were vaccinated by single dose but not the mandatory 3 doses so considered not effectively vaccinated; ${ }^{b}$ According to Egyptian law: 18 years; ${ }^{\circ}$ From primary to university; ${ }^{\prime}$ Including those below school entry age.

found between those negative and positive for $\mathrm{HBV}$ infection with regard to previous exposure to dental procedures, stitches, acupuncture and renal dialysis (Table 5).

Statistically significant differences were found between negative and positive cases of HCV infection regarding previous exposure to dental procedures, surgical operations, schistosomiasis

\begin{tabular}{|c|c|c|c|c|c|}
\hline \multicolumn{6}{|c|}{$\begin{array}{l}\text { Table } 2 \text { Hepatitis B virus (HBV) and hepatitis C virus (HCV) infection status of the } \\
\text { study sample }\end{array}$} \\
\hline \multirow{4}{*}{$\begin{array}{l}\text { HCV infection } \\
\text { status }\end{array}$} & \multicolumn{4}{|c|}{ HBV infection status } & \multirow[t]{4}{*}{$P$-value } \\
\hline & \multirow{2}{*}{\multicolumn{2}{|c|}{$\begin{array}{l}\text { Negative } \\
(n=2945)\end{array}$}} & \multirow{2}{*}{\multicolumn{2}{|c|}{$\begin{array}{c}\text { Positive } \\
(n=32)\end{array}$}} & \\
\hline & & & & & \\
\hline & No. & $\%$ & No. & $\%$ & \\
\hline Negative & 2679 & 91.0 & 20 & 62.5 & \multirow{2}{*}{$<0.001^{\mathrm{a}}$} \\
\hline Positive & 266 & 9.0 & 12 & 37.5 & \\
\hline
\end{tabular}

${ }^{a}$ Fisher exact test. treatment, contact with infected person, shared shaving razors, endoscopic examination, contaminated needle-stick, wet cupping, cauterization and tattooing (Table 6).

Risk factors already found significant in the bivariate analysis were reanalysed by a multivariate analysis. The risk of HBV infection was 2.8, 7.6 and 5.0 times higher among those exposed to previous stitches, renal dialysis and acupuncture respectively and the risk of $\mathrm{HCV}$ infection was 3.0, 2.8 and 1.4 times higher among those exposed to schistosomiasis treatment, wet cupping and contact with infected person respectively (Tables 7 and 8 ).

\section{Discussion}

Infection with $\mathrm{HBV}$ and $\mathrm{HCV}$ are major health problems worldwide, especially in developing countries. Egypt is still battling with the impact of these infections on the population's health due to the high prevalence of the diseases and their effects on longevity and morbidity (including decreases in health status, quality of life and severity and duration of disability), as well as their impact on the economy (including direct healthcare expenditures and indirect costs related to loss of income from premature death or disability). This study tried to estimate the seroprevalence and risk factors for HBV and HCV in Damietta Governorate, located in the north Delta area, and the effect of hepatitis B vaccination on seroprevalence.

The reported prevalence of HBsAg ranges from $3.0 \%$ to $11.0 \%$ in Egypt (10). In the present study, the detected total prevalence of HBsAgpositive cases was $1.1 \%$, less than the lowest reported national figure, and the majority of them had chronic infection. This rate was lower than that reported elsewhere in Egypt, in Ismailia (4.7\%) (11), in Turkey (8.1\%) (12), among high-risk hospitalized patients in Greece (2.7\%) (13), in Pakistan 


\begin{tabular}{|c|c|c|c|c|c|c|}
\hline \multirow[t]{3}{*}{ Variable } & \multicolumn{4}{|c|}{ HBV infection status } & \multirow[t]{3}{*}{$x^{2}$} & \multirow[t]{3}{*}{$P$-value } \\
\hline & \multicolumn{2}{|c|}{$\begin{array}{l}\text { Negative } \\
(n=2945)\end{array}$} & \multicolumn{2}{|c|}{$\begin{array}{c}\text { Positive } \\
(n=32)\end{array}$} & & \\
\hline & No. & $\%$ & No. & $\%$ & & \\
\hline \multicolumn{7}{|l|}{ Age (years) } \\
\hline$<19$ & 617 & 21.0 & 2 & 6.3 & & $0.046^{f}$ \\
\hline$\geq 19$ & 2328 & 79.0 & 30 & 93.7 & & \\
\hline \multicolumn{7}{|l|}{ Sex } \\
\hline Male & 1606 & 54.5 & 15 & 46.9 & & \multirow{2}{*}{$0.476^{f}$} \\
\hline Female & 1339 & 45.5 & 17 & 53.1 & & \\
\hline \multicolumn{7}{|l|}{ Marital status } \\
\hline Never married $^{\mathrm{a}}$ & 940 & 31.9 & 3 & 9.4 & & \multirow{2}{*}{$0.004^{f}$} \\
\hline Ever married ${ }^{b}$ & 2005 & 68.1 & 29 & 90.6 & & \\
\hline \multicolumn{7}{|l|}{ Education } \\
\hline Never been in education system ${ }^{c}$ & 1567 & 53.2 & 16 & 50.0 & \multirow{3}{*}{5.8} & \multirow{3}{*}{0.055} \\
\hline Enrolled in education system ${ }^{d}$ & 605 & 20.5 & 8 & 25.0 & & \\
\hline No longer in education system & 773 & 26.2 & 8 & 25.0 & & \\
\hline \multicolumn{7}{|l|}{ Occupation } \\
\hline Student & 605 & 20.5 & 8 & 25.0 & \multirow{4}{*}{5.4} & \multirow{4}{*}{0.093} \\
\hline Administrator & 193 & 6.6 & 1 & 3.1 & & \\
\hline Other & 975 & 33.1 & 9 & 28.1 & & \\
\hline Not working & 1172 & 39.8 & 14 & 43.8 & & \\
\hline
\end{tabular}

ancludes singles and those below marriage age; 'bncludes those currently in a marital union as well as divorced and widowed; "Includes those below school entry age, illiterate and read and write; ${ }^{d}$ From primary to university; ${ }^{e}$ Includes those below school entry age. fFisher exact test.

(2.5\%) (14) and among children in the Islamic Republic of Iran (1.8\%) (15). Whether this low prevalence can ascribed, for example, to sociodemographic factors and/or geographical location needs further study.

The study revealed that the prevalence of HCV infection among rural residents in Damietta Governorate was $9.3 \%$. This result agrees with the findings of previous studies among the general population of Egypt that attributed the higher figures in rural areas to the endemicity of schistosomiasis (16). There is evidence that large schistosomiasis control campaigns in the past that used repeated mass intravenous therapy with tartar emetic contributed to the establishment of a large reservoir of HCV infection in the population (17). Furthermore, other studies have observed that the seroprevalence rates of HCV were much higher in villages in the Nile Delta region compared with Upper Egypt and correlated with the difference in schistosomial infection rates in both regions (18-20). Other reports assumed that schistosomiasis-induced immune suppression could increase the persistence of viraemia following acute hepatitis B and C infections and this could partly explain the high prevalence of HCV infection in Egypt $(21,22)$. On the other hand, no association was observed between HCV and Schistosoma mansoni infection in endemic areas in Brazil (23).

Egypt is one of the highest HCV seroprevalence areas, with a prevalence of infection ranging from $10.0 \%$ to $25.0 \%$ (24). In the present study, the detected total seroprevalence of $\mathrm{HCV}$ was slightly lower than the lower limit of the recorded national range. This rate also was lower than that reported elsewhere in Egypt in Ismailia, (14.9\%)
(11) but higher than that reported in Greece (4.7\%) (13), in Turkey (0.5\%) (12) and in Pakistan (1.6\%) (14). This could confirm the endemicity of HCV in Egypt.

The most important risk factors for $\mathrm{HBV}$ and HCV infections detected in our study were previous exposure to dental procedures (significant for both infections), stitches (significant for HBV infection), surgical operations, contact with infected person and schistosomiasis treatment (significant for $\mathrm{HCV}$ infection). This might reflect the role of contaminated surgical procedures, bad sterilization and deficient infection control programmes in our hospitals, private clinics and homes in the transmission of HBV and HCV in Egypt. These results agreed with the report of the National Institutes of Health about HCV infection (25), an Iranian study which gave nearly the same 


\begin{tabular}{|c|c|c|c|c|c|c|}
\hline \multirow[t]{3}{*}{ Variable } & \multicolumn{4}{|c|}{ HCV infection status } & \multirow[t]{3}{*}{$x^{2}$} & \multirow[t]{3}{*}{$P$-value } \\
\hline & \multicolumn{2}{|c|}{$\begin{array}{l}\text { Negative } \\
(n=2699)\end{array}$} & \multicolumn{2}{|c|}{$\begin{array}{l}\text { Positive } \\
(n=278)\end{array}$} & & \\
\hline & No. & $\%$ & No. & $\%$ & & \\
\hline \multicolumn{7}{|l|}{ Age (years) } \\
\hline$<19$ & 598 & 22.2 & 21 & 7.6 & & \multirow{2}{*}{$<0.001^{1}$} \\
\hline$\geq 19$ & 2101 & 77.8 & 257 & 92.4 & & \\
\hline \multicolumn{7}{|l|}{ Sex } \\
\hline Male & 1461 & 54.1 & 160 & 57.6 & & \multirow{2}{*}{$0.28^{f}$} \\
\hline Female & 1238 & 45.9 & 118 & 42.4 & & \\
\hline \multicolumn{7}{|l|}{ Residence } \\
\hline Urban & 860 & 31.9 & 1 & 0.4 & & \multirow{2}{*}{$<0.001^{1}$} \\
\hline Rural & 1839 & 68.1 & 277 & 99.6 & & \\
\hline \multicolumn{7}{|l|}{ Marital status } \\
\hline Never married ${ }^{a}$ & 901 & 33.4 & 42 & 15.1 & & \multirow{2}{*}{$<0.001^{\prime}$} \\
\hline Ever married ${ }^{\mathrm{b}}$ & 1798 & 66.6 & 236 & 84.9 & & \\
\hline \multicolumn{7}{|l|}{ Education } \\
\hline Never been in education system ${ }^{c}$ & 1406 & 52.1 & 177 & 63.7 & \multirow{3}{*}{26.6} & \multirow{3}{*}{$<0.001$} \\
\hline Enrolled in education system ${ }^{d}$ & 588 & 21.8 & 25 & 9.0 & & \\
\hline No longer in education system & 705 & 26.1 & 76 & 27.3 & & \\
\hline \multicolumn{7}{|l|}{ Occupation } \\
\hline Student & 588 & 21.8 & 25 & 9.0 & \multirow{4}{*}{29.7} & \multirow{4}{*}{$<0.001$} \\
\hline Administrator & 165 & 6.1 & 29 & 10.4 & & \\
\hline Other & 883 & 32.7 & 101 & 36.3 & & \\
\hline Not working & 1063 & 39.4 & 123 & 44.2 & & \\
\hline
\end{tabular}

aIncludes singles and those below the marriage age; ${ }^{b}$ Includes those currently in a marital union as well as divorced and widowed; ' Includes those below school entry age, illiterate and read and write; ${ }^{d}$ From primary to university; ${ }^{e}$ Includes those below school entry age. ${ }^{f}$ Fisher exact test.

results regarding HBV infection (26) and a study of the relationship between therapeutic injections using non-sterile needles and the transmission of HBV and $\mathrm{HCV}(27)$.

Other risk factors, such as exposure to acupuncture (significant in HBV infection), wet cupping, shared shaving razors, endoscopic examination, tattooing and cauterization (significant in HCV infection), played a role in transmission of HBV and HCV in our study, but to a lesser extent. Similar results were reported in the Islamic Republic of Iran (26) and in Pakistan (28). However, in a country such as Pakistan, which is located in an intermediate HBV prevalence area, blood transfusion is still the major cause of HBV and HCV transmission (29).
Vaccination against HBV was enrolled in routine immunization in Egypt since 1991. Our results revealed that the majority of patients infected with HBV (93.7\%) were not vaccinated against hepatitis B (i.e. were older than 19 years) and this might reflect the importance of vaccination in preventing the infection. In an Italian study, no infected cases were reported among fully vaccinated children (30), implying that increasing the vaccination coverage rate will give full protection against the disease. Though they reported a history of hepatitis B vaccination, 2 subjects (both aged $<19$ years) had HBV infection and this might be ascribed to a reporting error, ineffective vaccine or the reported $5 \%$ inefficacy rate of the vaccine (31).
The implication of this study is that seropositivity was comparatively higher for anti-HCV among the study sample than for HBsAg and the difference between the prevalences of the 2 diseases was statistically significant. This suggests that, with exposure to nearly the same risk factors, the routine use of $\mathrm{HBV}$ vaccine might avert the infection to a large extent.

There were some limitations of the study. Due to resource constraints, the study was restricted to serological but not confirmatory tests, as polymerase chain reaction and viral load testing was not performed. The study did not measure the prevalence of these viruses according to acute and chronic infections. Due to religious beliefs, illegal intercourse is not common in the 


\begin{tabular}{|c|c|c|c|c|c|}
\hline \multirow[t]{3}{*}{ Variable } & \multicolumn{4}{|c|}{ HBV infection status } & \multirow[t]{3}{*}{$P$-value } \\
\hline & \multicolumn{2}{|c|}{$\begin{array}{l}\text { Negative } \\
(n=2945)\end{array}$} & \multicolumn{2}{|c|}{$\begin{array}{c}\text { Positive } \\
(n=32)\end{array}$} & \\
\hline & No. & $\%$ & No. & $\%$ & \\
\hline Dental procedure & 1663 & 56.5 & 24 & 75.0 & 0.040 \\
\hline Previous stitches & 969 & 32.9 & 20 & 62.5 & 0.001 \\
\hline Surgical operation & 1017 & 34.5 & 14 & 43.8 & 0.270 \\
\hline Schistosomiasis treatment & 533 & 18.1 & 6 & 18.8 & 0.821 \\
\hline Contact with infected person & 508 & 17.2 & 5 & 15.6 & 1.000 \\
\hline Wet cupping & 129 & 4.4 & 3 & 9.4 & 0.171 \\
\hline Acupuncture & 44 & 1.5 & 3 & 9.4 & 0.011 \\
\hline Blood transfusion & 293 & 9.9 & 2 & 6.3 & 0.772 \\
\hline Shared shaving razor & 402 & 13.7 & 2 & 6.3 & 0.301 \\
\hline Shared toothbrush & 125 & 4.2 & 2 & 6.3 & 0.402 \\
\hline Suction tube & 45 & 1.5 & 2 & 6.3 & 0.090 \\
\hline Cauterization & 52 & 1.8 & 2 & 6.3 & 0.113 \\
\hline Renal dialysis & 18 & 0.6 & 2 & 6.3 & 0.024 \\
\hline Endoscopic examination & 163 & 5.5 & 2 & 6.3 & 0.704 \\
\hline Contaminated needle-stick & 121 & 4.1 & 1 & 3.1 & 0.801 \\
\hline Tattoo & 27 & 0.9 & 1 & 3.1 & 0.262 \\
\hline Extramarital sexual intercourse & 19 & 0.7 & 1 & 3.1 & 0.094 \\
\hline
\end{tabular}

${ }^{a}$ Fisher exact test.

\begin{tabular}{|c|c|c|c|c|c|}
\hline \multirow[t]{3}{*}{ Variable } & \multicolumn{4}{|c|}{ HCV infection status } & \multirow[t]{3}{*}{$P$-value ${ }^{a}$} \\
\hline & \multicolumn{2}{|c|}{$\begin{array}{l}\text { Negative } \\
(n=2699)\end{array}$} & \multicolumn{2}{|c|}{$\begin{array}{l}\text { Positive } \\
(n=278)\end{array}$} & \\
\hline & No. & $\%$ & No. & $\%$ & \\
\hline Dental procedure & 1499 & 55.5 & 188 & 67.6 & $<0.001$ \\
\hline Surgical operation & 908 & 33.6 & 123 & 44.2 & 0.001 \\
\hline Schistosomiasis treatment & 430 & 15.9 & 109 & 39.2 & $<0.001$ \\
\hline Previous stitches & 888 & 32.9 & 101 & 36.3 & 0.262 \\
\hline Contact with infected person & 444 & 16.5 & 69 & 24.8 & 0.001 \\
\hline Shared shaving razor & 347 & 12.9 & 57 & 20.5 & 0.001 \\
\hline Wet cupping & 95 & 3.5 & 37 & 13.3 & $<0.001$ \\
\hline Blood transfusion & 261 & 9.7 & 34 & 12.2 & 0.173 \\
\hline Endoscopic examination & 137 & 5.1 & 28 & 10.1 & 0.001 \\
\hline Shared toothbrush & 114 & 4.2 & 13 & 4.7 & 0.750 \\
\hline Contaminated needle-stick & 104 & 3.9 & 18 & 6.5 & 0.043 \\
\hline Cauterization & 42 & 1.6 & 12 & 4.3 & 0.003 \\
\hline Tattoo & 22 & 0.8 & 6 & 2.2 & 0.041 \\
\hline Acupuncture & 41 & 1.5 & 6 & 2.2 & 0.442 \\
\hline Suction tube & 41 & 1.5 & 6 & 2.2 & 0.442 \\
\hline Extramarital sexual intercourse & 19 & 0.7 & 1 & 0.4 & 0.501 \\
\hline Renal dialysis & 16 & 0.6 & 4 & 1.4 & 0.114 \\
\hline
\end{tabular}

${ }^{a}$ Fisher exact test. 


\begin{tabular}{|c|c|c|c|c|}
\hline \multirow[t]{2}{*}{ Risk factor } & \multicolumn{4}{|c|}{ HBsAg seropositivity } \\
\hline & B & $\operatorname{Exp} B$ & $\begin{array}{c}95 \% \mathrm{Cl} \text { for } \\
\exp B\end{array}$ & $P$-value \\
\hline Previous stitches & 1.0 & 2.8 & $1.3-5.9$ & 0.008 \\
\hline Renal dialysis & 2.0 & 7.6 & $1.6-36.4$ & 0.011 \\
\hline Acupuncture & 1.6 & 5.0 & $1.4-17.8$ & 0.012 \\
\hline Dental procedure & 0.6 & 1.7 & $0.7-4.1$ & 0.207 \\
\hline
\end{tabular}

$\mathrm{Cl}=$ confidence interval.

\begin{tabular}{|c|c|c|c|c|}
\hline \multirow[t]{2}{*}{ Risk factor } & \multicolumn{4}{|c|}{ Anti-HCV seropositivity } \\
\hline & B & $\operatorname{Exp} B$ & $\begin{array}{c}95 \% \mathrm{Cl} \text { for } \\
\exp B\end{array}$ & $P$-value \\
\hline Schistosomiasis treatment & 1.1 & 3.0 & $2.2-3.8$ & $<0.001$ \\
\hline Wet cupping & 1.0 & 2.8 & $1.8-4.3$ & $<0.001$ \\
\hline Contact with infected person & 0.3 & 1.4 & $1.0-1.9$ & 0.045 \\
\hline Dental procedure & 0.2 & 1.2 & $0.9-1.6$ & 0.261 \\
\hline Surgical operation & 0.2 & 1.2 & $0.9-1.6$ & 0.221 \\
\hline Shared shaving razor & 0.03 & 1.0 & $0.7-1.5$ & 0.865 \\
\hline Endoscopic examination & 0.01 & 1.0 & $0.6-1.6$ & 0.981 \\
\hline Contaminated needle-stick & -0.2 & 0.8 & $0.4-1.6$ & 0.544 \\
\hline Cauterization & 0.5 & 1.6 & $0.8-3.3$ & 0.168 \\
\hline Tattoo & 0.4 & 1.5 & $0.6-4.0$ & 0.425 \\
\hline
\end{tabular}

$\mathrm{Cl}=$ confidence interval.

Egyptian community and we therefore suspected that we might not have received truthful answers to this question.
Some members of households refused to participate in the study for different reasons and others were not present at the time of the survey. The actual rates of refusal and non-response were not determined and both were omitted from analysis. Finally, the questionnaire did not fully address socioeconomic factors such as income, which generally is a good indicator of low awareness of viral disease transmission.

\section{Conclusion}

The prevalence of HBV and HCV in Damietta Governorate is close to the lowest reported national figure. The prevalence of HBV appears to have declined after the introduction of the HBV vaccine. Those infected with HBV and HCV were exposed to various risk factors for infection by different degrees, with dental and surgical procedures being the most important. Proper sterilization of dental and surgical instruments and activating infection control procedures in health-care settings are important to reduce the risk of infection. There is a need to educate the general population about $\mathrm{HBV}$ and $\mathrm{HCV}$ transmission routes, risk factors and avoidance of risky behaviours. Further studies addressing the quality and safety of dental and surgical procedures are needed.

Competing interests: None declared.

\section{References}

1. Haydon GH, Jarvis LM, Simmonds P, Harrison DJ, Garden OJ, Hayes PC. Association between chronic hepatitis C infection and hepatocellular carcinoma in a Scottish population. Gut. 1997 Jan;40(1):128-32. PMID:9155590

2. Freeman RB Jr. Diagnosing hepatocellular carcinoma: a virtual reality. Liver Transpl. 2002 Sep;8(9):762-4. PMID:12200774

3. Féray C, Gigou M, Samuel D, Reyes G, Bernuau J, Reynes M, et al. Hepatitis $C$ virus RNA and hepatitis B virus DNA in serum and liver of patients with fulminant hepatitis. Gastroenterology. 1993 Feb;104(2):549-55. PMID:8381098

4. Kew MC, Yu MC, Kedda MA, Coppin A, Sarkin A, Hodkinson J. The relative roles of hepatitis $B$ and $C$ viruses in the etiology of hepatocellular carcinoma in southern African blacks. Gastroenterology. 1997 Jan;112(1):184-7. PMID:8978357

5. Wasley A, Alter MJ. Epidemiology of hepatitis C: geographic differences and temporal trends. Semin Liver Dis. 2000;20(1):1-16. PMID:10895428

6. Egyptian national control strategy for viral hepatitis 2008-2012. Cairo: National Committee for the Control of Viral Hepatitis,
Ministry of Health and Population; 2008 (http://www.pasteur.fr/ip/resource/filecenter/document/01s-00002i-03t/ nsp-10-april-2008-final.pdf, accessed 20 July 2014).

7. Mohamed M. Epidemiology of HCV in Egypt. Afro-arab Liver J. 2004;3(2):45-57.

8. Kamal SM, Nasser IA. Hepatitis C genotype 4: What we know and what we don't yet know. Hepatology. 2008 Apr;47(4):1371-83. PMID:18240152

9. Data of the governorates of Arab Republic of Egypt [Internet]. Cairo: Egyptian Cabinet, Information and Decision Support Center, National Information Sector; 2005 (http://www.IDSC. gov.eg, accessed 20 July 2014).

10. Inter-country workshop on the prevention and control of viral hepatitis. Alexandria: World Health Organization, Regional Office for the Eastern Mediterranean; 1995.

11. Youssef A, Yano Y, Utsumi T, abd El-alah EM, abd El-Hameed Ael-E, Serwah Ael-H, et al. Molecular epidemiological study of hepatitis viruses in Ismailia, Egypt. Intervirology. 2009;52(3):123-31. PMID:19468235 
12. Kangin M, Turhanoglu M, Gulsun S, Cakabay B. Seroprevalence of hepatitis B and C among children in endemic areas of Turkey. Hepat Mon. 2010 Winter;10(1):36-41. PMID:22308124

13. Koulentaki M, Ergazaki M, Moschandrea J, Spanoudakis S, Tzagarakis N, Drandakis PE, et al. Prevalence of hepatitis B and $\mathrm{C}$ markers in high-risk hospitalised patients in Crete: a five-year observational study. BMC Public Health. 2001;1:17. PMID:11806759

14. Khokhar N, Gill ML, Malik GJ. General seroprevalence of hepatitis $C$ and hepatitis B virus infections in population. J Coll Physicians Surg Pak. 2004 Sep;14(9):534-6. PMID:15353136

15. Alavian S, Fallahian F, Lankarani K. Comparison of seroepidemiology and transmission modes of viral hepatitis B in Iran and Pakistan. Hepat Mon. 2007;7(4):233-8.

16. Blanton RE, Salam EA, Kariuki HC, Magak P, Silva LK, Muchiri EM, et al. Population-based differences in Schistosoma mansoni- and hepatitis C-induced disease. J Infect Dis. 2002 Jun 1;185(11):1644-9. PMID:12023771

17. Frank C, Mohamed MK, Strickland GT, Lavanchy D, Arthur RR, Magder LS, et al. The role of parenteral antischistosomal therapy in the spread of hepatitis C virus in Egypt. Lancet. 2000 Mar 11;355(9207):887-91. PMID:10752705

18. Nafeh MA, Medhat A, Shehata M, Mikhail NN, Swifee Y, AbdelHamid $M$, et al. Hepatitis C in a community in Upper Egypt: I. Cross-sectional survey. Am J Trop Med Hyg. 2000 NovDec;63(5-6):236-41. PMID:11421370

19. Habib M, Mohamed MK, Abdel-Aziz F, Magder LS, Abdel-Hamid M, Gamil F, et al. Hepatitis C virus infection in a community in the Nile Delta: risk factors for seropositivity. Hepatology. 2001 Jan;33(1):248-53. PMID:11124843

20. Medhat A, Shehata M, Magder LS, Mikhail N, Abdel-Baki L, Nafeh $M$, et al. Hepatitis c in a community in Upper Egypt: risk factors for infection. Am J Trop Med Hyg. 2002 May;66(5):6338. PMID:12201604

21. Ghaffar YA, Fattah SA, Kamel M, Badr RM, Mahomed FF, Strickland GT. The impact of endemic schistosomiasis on acute viral hepatitis. Am J Trop Med Hyg. 1991 Dec;45(6):743-50. PMID:1763802

22. El-Zayadi AR. Curse of schistosomiasis on Egyptian liver. World J Gastroenterol. 2004 Apr 15;10(8):1079-81. PMID:15069702

23. Tavares-Neto J, Prata A, Paraná R, Valente VB, Vitvitski L, Figueiredo JF. Very low prevalence of hepatitis $C$ virus infection in rural communities of northeastern Brazil with a high prevalence of schistosomiasis mansoni. Rev Soc Bras Med Trop. 2005 JulAug;38(4):290-3. PMID:16082473

24. Alter MJ. Epidemiology of hepatitis $C$ virus infection. World J Gastroenterol. 2007 May 7;13(17):2436-41. PMID:17552026

25. Jonas MM. Management of hepatitis C: 2002. Children with hepatitis C. Report to National Institutes of Health Consensus Development Conference. June 10-12, 2002. Bethesda (MD): National Institutes of Health; 2002 http://consensus.nih.gov/ 2002/2002hepatitisc2002116html.htm, accessed 20 July 2014).

26. Merat S, Rezvan H, Nouraie M, Jamali A, Assari S, Abolghasemi $\mathrm{H}$, et al. The prevalence of hepatitis B surface antigen and antihepatitis B core antibody in Iran: a population-based study. Arch Iran Med. 2009 May;12(3):225-31. PMID:19400598

27. Khan AJ, Luby SP, Fikree F, Karim A, Obaid S, Dellawala S, et al. Unsafe injections and the transmission of hepatitis $B$ and $C$ in a periurban community in Pakistan. Bull World Health Organ. 2000;78(8):956-63. PMID:10994278

28. Bari A, Akhtar S, Rahbar MH, Luby SP. Risk factors for hepatitis $C$ virus infection in male adults in Rawalpindi-Islamabad, Pakistan. Trop Med Int Health. 2001 Sep;6(9):732-8. PMID:11555441

29. Luby S, Khanani R, Zia M, Vellani Z, Ali M, Qureshi AH, et al. Evaluation of blood bank practices in Karachi, Pakistan, and the government's response. Health Policy Plan. 2000 Jun;15(2):217-22. PMID:10837045

30. Broderick A, Jonas MM. Management of hepatitis B in children. Clin Liver Dis. 2004 May;8(2):387-401. PMID:15481346

31. Hepatitis B. Fact sheet No. 204 [Internet]. Geneva: World health Organization; 2013 http://www.who.int/mediacentre/ factsheets/fs204/en/index.html, accessed 20 July 2014). 